Standard for Antimicrobial Susceptibility Testing: Eighth Informational Supplement. NCCLS document M100-S9. Vilianova, PA: NCCLS; 1999.

22. Hsueh PR, Teng LJ, Yang PC, Chen YC, Ho SW, Luh KT. Persistence of a multidrug-resistant Pseudomonas aeruginosa clone in an intensive care burn unit. J Clin Microbiol 1998;36:1347-1351.

23. Clark NC, Cooksey RC, Hill BC, Swenson JM, Tenover FC. Characterization of glycopeptide-resistant enterococci from US hospitals. Antimicrob Agents Chemother 1993;37:2311-2317.

24. Livornese LLJr, Dias S, Samel C, Romanowski B, Taylor S, May P, et al. Hospital-acquired infection with vancomycin-resistant Enterococcus faecium transmitted by electronic thermometers. Ann Intern Med 1992;117:112-116.

25. Collins LA, Malanoski GJ, Eliopoulos GM, Wennersten CB, Ferraro MJ,
Moellering RC Jr. In vitro activity of RP59500, an injectable streptogramin antibiotic, against vancomycin-resistant gram-positive organisms. Antimicrob Agents Chemother 1993;37:598-601.

26. Evans PA, Norden CW, Rhoads S, Deobaldia J, Silber JL. In vitro susceptibilities of clinical isolates of vancomycin-resistant enterococci. Antimicrob Agents Chemother 1997;41:1406.

27. Freeman C, Robinson A, Cooper B, Mazens-Sullivan M, Quintiliani R, Nightingale $\mathbf{C}$. In vitro antimicrobial susceptibility of glycopeptide-resistant enterococci. Diagn Microbiol Infect Dis 1995;21:47-50.

28. Lucas GM, Lechtzin N, Puryear DW, Yau LL, Flexner CW, Moore RD. Vancomycin-resistant and vancomycin-susceptible enterococcal bacteremia: comparison of clinical features and outcomes. Clin Infect Dis 1998;26:1127-1133

\title{
Outbreak of Echovirus in a Neonatal Unit
}

\section{Gina Pugliese, RN, MS Martin S. Favero, PhD}

Chambon and coinvestigators from Centre Hospitalier Universitaire, Clermont-Ferrand, France, reported an outbreak of echovirus type 30. Between February and August 1997, 53 patients with enterovirus meningitis were hospitalized. All but 1 were children. Echovirus type 30 was involved in $70 \%$ of cases with identified serotype. The outbreak ceased on August 8. Two months later, a neonate was admitted to the neonatal unit with an echovirus type 30 meningitis thought to be acquired at deliv- ery. Twenty days later, a nosocomial outbreak of echovirus type 30 involving 5 neonates occurred. Two of them presented with meningitis and 2 with febrile seizure; 1 was asymptotic. The retrospective examination of the maternal sera in a neutralization test, using the index case strain as a source of antigen, showed that none of the neonates was passively immunized before hospitalization. The use of genome detection in cerebrospinal fluid allowed rapid diagnosis, and infection was contained by reinforcing hygiene measures. Prospective examination of stools in the neonatal and pediatric units showed no further occurrences of the disease. No spo- radic case was observed in the general population.

The authors point out that nosocomial infections can occur a long time after an outbreak in the general population; rapid diagnosis with molecular tools is useful both for a definite diagnosis in patients already hospitalized and to act as a rapid alert, even in intervals between seasonal outbreaks.

FROM: Chambon M, Bailly JL, Beguet A, Henquell C, Archimbaud C, Gaulme J, et al. An outbreak due to echovirus type 30 in a neonatal unit in France in 1997: usefulness of PCR diagnosis. J Hosp Infect 1999;43:63-68. 